\title{
Prediction of Dissolution of Copper from a Chalcopyrite Carbonatite Ore of South Africa
}

\author{
Brad Barlow, Elvis Fosso-Kankeu*, Kolela J Nyembwe, Frans Waanders and Edward Ntumba Malenga
}

\begin{abstract}
Chalcopyrite accounts for $70 \%$ of all copper bearing minerals and therefore has been studied closely to understand the dissolution kinetics in hope of overcoming the passivation film and increasing the extraction rates of copper. In this study carbonatite samples were obtained from a mining company in South Africa. The carbonatite samples were leached and the leachates were assessed for the metal ions content, $\mathbf{p H}$, electrical conductivity (EC), RedOx potential (RP), acidity, major anions (sulphate, chloride) as well as iron ion concentration for speciation prediction. Speciation of metal ions was conducted through the use of PHREEQC modelling software. The main objective of the study was to determine the kinetic dissolution pattern of the run of mine (ROM) chalcopyrite samples from the carbonatite host rock over time as a varying factor. The mineralogical investigation showed that the ROM sample was dominated by calcite magnesium (Ca0.97 Mg $0.03\left(\mathrm{CO}_{3}\right)$ ). The elemental investigation showed that the sample was dominated by $\mathrm{Ca}$ and $\mathrm{Fe}$ with mass \% of 49.81 and 26.31 respectively. The dissolution curve for copper displayed and overall decrease in dissolution rate of copper clearly showing the effects of passivation on the chalcopyrite mineral; a peak dissolution rate $(\mathbf{2 2 . 8 \%})$ was observed after 7 hours of leaching. From the ICP data the major cation in the leachate of the ROM was determined to be $\mathrm{Ca}, \mathrm{Cu}, \mathrm{Fe}$ and $\mathrm{Mg}$. The PHREEQC results showed that $\mathrm{Ca}, \mathrm{Cu}$ and $\mathrm{Mg}$ was dominant as sulphate salt species while $\mathrm{Fe}$ was dominant as a free ionic species $\left(\mathrm{Fe}^{2+}\right)$.
\end{abstract}

Keywords - Carbonatite ores, Chalcopyrite, kinetic dissolution, $\mathrm{pH}$, passivation, ORP, ROM, XRF, XRD.

\section{INTRODUCTION}

Copper is found in various ore bodies each with their own challenges effecting the extraction process. Chalcopyrite, accounting for $70 \%$ of all copper bearing minerals, has various challenges hindering the leaching process [1]. Most industrial applications make use of pyrometallurgical methods (80-85\% of

Elvis Fosso-Kankeu is with the Water Pollution Monitoring and Remediation Initiatives Research Group, School of Chemical and Minerals Engineering, Faculty of Engineering, North-West University, South Africa..

Frans Waanders is with the Water Pollution Monitoring and Remediation Initiatives Research Group, School of Chemical and Minerals Engineering, Faculty of Engineering, North-West University, South Africa.

Brad Barlow is with the Water Pollution Monitoring and Remediation Initiatives Research Group, School of Chemical and Minerals Engineering, Faculty of Engineering, North-West University, South Africa.

Kolela J Nyemba is with the Water Pollution Monitoring and Remediation Initiatives Research Group, School of Chemical and Minerals Engineering, Faculty of Engineering, North-West University, South Africa.

Edward Ntumba Malenga is with Mineral Processing and Technology Research Centre, Department of Metallurgy, School of Mining, Metallurgy and Chemical Engineering, Faculty of Engineering and the Built Environment, University of Johannesburg. copper extracted from chalcopyrite) although it is not considered to be eco-friendly [2]. Hydrometallurgical methods are both more economical as well as environmental friendly than pyrometallurgical methods but are not widely applied in the industry as the current methods deliver lower extraction as opposed to the latter [2]. Compared to other sulphide copper-bearing minerals, such as chalcocite, chalcopyrite delivers lower extraction rates. The low extraction rate are believed to be a result of a passivation film forming on the chalcopyrite surface [1]. Passivation refers to the state at which a material is considered to become passive i.e. when a material is described as being less effected or corroded by the surrounding environment. During passivation an outer layer is said to form on the surface of the material due to chemical interactions with other substances [3]. Passivation is not always desired; such is the case of chemical leaching of chalcopyrite. During the treatment of chalcopyrite, a passivation film is formed which decreases the effects of the lixiviate on the ore body substantially decreasing the rate at which copper is leached from the surface of the ore body by acting as a shield, thus subsequently preventing interaction of the lixiviate with the surface [1]. Passivation is only said to occur under certain condition and in the case of chalcopyrite there have been numerous conditions studied as to identify the origins of chalcopyrite passivation. The formation of elemental sulphur produced during the ferric leaching of chalcopyrite as well as pollysulphides forming as a result of solid state changes have both been assumed to be the cause of the passivation film but have since been disproven [4]. Metal deficient layers building up progressively during the mineral dissolution on the mineral surface has also been assumed to be the cause and have also since been disproven. Different ore bodies will affect the leaching rate of copper in these ore bodies as the particle size distribution, presence of various elements etc. will differ. Previous studies indicated that the leaching performance depends on the interaction of the solids, contained within the host rock, with the lixiviate as well as the associated gangue species present within the host rock [5]. South Africa's leading copper producer is the Rio Tinto Copper Mine in Phalaborwa, Limpopo with majority shares held by Rio Tinto plc Error! Reference source not found.. The copper ore body from the Rio Tinto mine is hosted in a carbonatite in which the highest values (1.0\%copper) are present at the core. The carbonatite complex is also geologically unique as it is the only carbonatite complex in the world containing sufficient amounts of copper sulfide minerals for the operations to be economically feasible [17]. Due to the carbonatite complex being unique in its nature as a copper-sulphide host rock it is well suited to test the effects of mineralogy on the dissolution of copper. In this study the 
dissolution behaviour of copper bearing ore samples from a South African mine are observed to determine the impact of passivation on the recovery of copper from carbonatite ROM feed stream samples.

\section{EXPERIMENTAL SETUP AND MODELLING}

\section{A. Materials}

Carbonatite samples used for the study was provided by a local mining company. The ROM samples were first crushed to -150 micron using a ball mill and then stored in the tight seal plastic containers before use. The provided samples were characterized in our previous study and the results reported (Figures 1 and 2) [18].

\section{B. Chalcopyrite sample characterization}

In the published paper by Nyembwe et al. [18], the characterization of the host rock was conducted by determining the chemical and mineralogical composition, the surface topography and the particle size distribution for the concentrates, ROM and tailings samples. X-ray florescence (using a MagiX Pro \& Super Q X-ray Fluorimeter) \& X-ray photoelectron spectroscopy were used for the chemical composition, X-ray diffraction (using a Philips X'Pert pro MPD $\mathrm{X}$-ray diffractometer) for the mineralogical composition and scanning electron microscopy for surface topography. Malvern master-sizer equipment was used for the determination of particle size distribution. The previous study concluded the following for the XRD and XRF analyses:

\section{1) Mineralogical investigation (XRD)}

Fig 1 shows the distribution of the identified minerals, in weight percentage, for the analyzed plant stream samples. The dominant species available in the ROM sample was calcite magnesium (67.92\%). The younger carbonatites formed at the Palabora Carbonatitic Complex are described as being intrusive [19] which carbonate minerals are known to be principle constituent of, with approximately $60 \%$ of the world's intrusive carbonatites consisting of predominantly calcite thus explaining the high concentration of calcite magnesium, as well as dolomite (being the second highest concentration at $16.67 \%$ )[20]. Besides chalcopyrite, the rest of the carbonatite host rock consisted of minerals species of magnetite (one of the main iron ores) and silica at $10.61 \%$ and $6 \%$ respectively. The chalcopyrite concentration analysed was relatively small at $1.54 \%$.

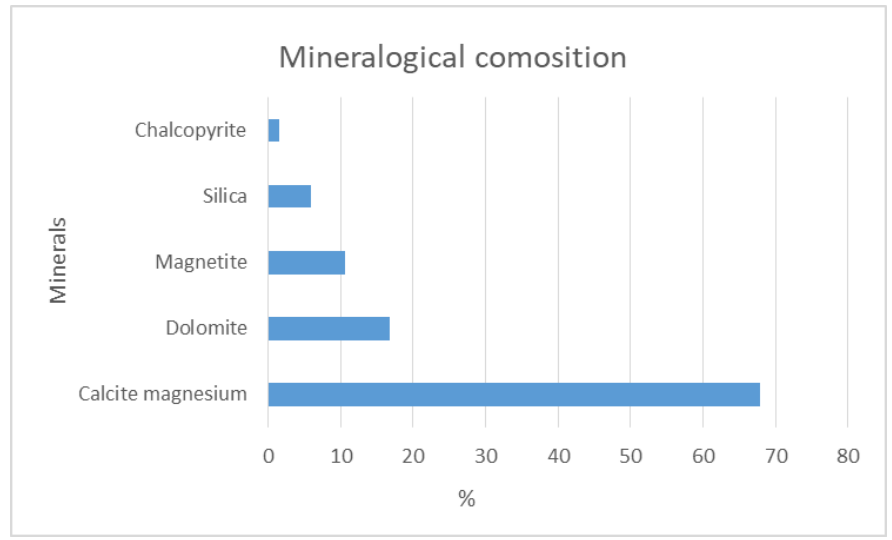

Fig 1: Mineralogical composition of feed stream samples

\section{2) Chemical/elemental investigation $(X R F)$}

Fig 2 represents the bulk stream chemical/elemental composition of the metals with the highest concentration in the plant feed stream sample (ROM). Calcium (Ca) was determined to be the main component in the ROM stream at $49.8 \%$. Iron $(\mathrm{Fe})$, with the second highest concentration, is present at $26.3 \%$ with smaller concentration of $\mathrm{Mg}(5.7 \%), \mathrm{Si}(4.7 \%), \mathrm{Cu}(4.5 \%)$, $\mathrm{P}(2.8 \%)$ and $\mathrm{S}(1.4 \%)$. Other elements were also observed during the chemical investigation at $<1 \%$ range, these elements include: $\mathrm{Al}, \mathrm{Cl}, \mathrm{K}, \mathrm{Mn}, \mathrm{Na}, \mathrm{Sr}, \mathrm{Ti}, \mathrm{Zn}$ and $\mathrm{Zr}$.

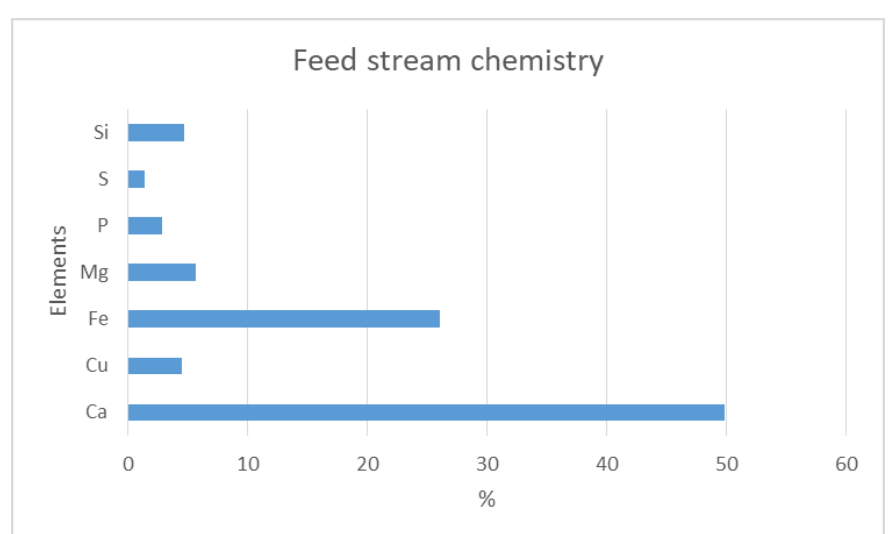

Fig 2: Chemical composition of feed stream samples (main elements)

\section{Chemical leaching (Shake flask tests)}

For the chemical leaching of the chalcopyrite feed stream samples (ROM samples) an incubator with a built in orbital shaker was used; the incubator was used to keep both the temperature and rotational speed $(200 \mathrm{rpm})$ stable during experimental runs. The experiment was carried out in triplicate at varying experimental conditions. Using $500 \mathrm{~mL}$ volumetric flasks, a $10 \%$ solids to liquid solution was prepared; the liquid solution was prepared using distilled water, sulphuric acid and ferric sulphate to produce a ferric sulphate solution of $0.1 \mathrm{M}$. The volumetric flasks were then shaken at $200 \mathrm{rpm}$ at $45^{\circ} \mathrm{C}$ for a period of 12 hours. The $\mathrm{pH}$ was also kept stable between values of 0.5 and 2; diluted sulphuric acid solution was added if $\mathrm{pH}$ exceeded a value of 2 . From the ROM solution $30 \mathrm{~mL}$ was extracted at hourly intervals and filtered; the filtered residue was then dried and stored for later use. 


\section{Leachate analyses}

Each leachates sample obtained during filtering of the chalcopyrite solutions were measured for $\mathrm{pH}$, temperature, electrical conductivity (EC), and RedOx potential (RP). Samples were also collected for the determination of sulphate ion concentration, chloride ion concentration, iron ion concentration and acidity. The leachate was also analysed for metal ion concentration by means of inductively coupled plasma-optical emission spectrometry (ICP-OES). The $\mathrm{pH}, \mathrm{RP}$ and temperature of each leachate sample was measured using a portable $\mathrm{pH}$ meter with an analytical electrode HI8424 (Hanna Instruments Inc.); a conductivity meter with an electrode was used to measure the electrical conductivity. A COD and Multiparameter Photometer HI 83099 was used for sulphate ion concentration from the selected samples.

\section{E. Titration tests}

The acidity was measured through titration method with $0.02 \mathrm{~N}$ sodium hydroxide $(\mathrm{NaOH})$ where $0.02 \mathrm{~N}$ sodium carbonate $\left(\mathrm{Na}_{2} \mathrm{CO}_{3}\right)$ was used as standardization procedure. For chloride ion concentration, titration was conducted using silver nitrate $\left(\mathrm{AgNO}_{3}\right)$ and potassium dichromate $\left(\mathrm{K}_{2} \mathrm{CrO}_{4}\right)$ as indicator Error! Reference source not found. For iron ion concentration, titration was conducted using potassium dichromate $\left(\mathrm{K}_{2} \mathrm{CrO}_{4}\right)$ and ortho-diphenylamine sulphonate as indicator.

\section{F. Speciation modeling}

To determine the aqueous speciation of the major metal ions in the leachate of the ROM feed stream sample, AQUACHEM software was used interfaced with PHREEQC (program version 3.3.12-12704.) modelling software Error! Reference source not found.. The phreeqc database, Minteq.v4.dat was used for the purpose of this report. The RP had to be adjusted with a correction factor before it could be used as input data. The correction factor was obtained from Field Measurements of Oxidation-Reduction Potential [27]. The corrected ORP value was then used to calculate the pe value using the following equation:

$$
\mathrm{pe}=\mathrm{E} \_\mathrm{h} /(0.059)
$$

$p e$ donates the negative logarithm of the electron activity $E_{h}$ donates the oxidation redox potential of the sample

\section{RESULTS AND DISCUSSION}

\section{A. Free pH test}

A pre-analysis was conducted before the $\mathrm{ROM}$ run at $45^{\circ} \mathrm{C}$ to monitor the change in $\mathrm{pH}$ without the addition of sulphuric acid $\left(\mathrm{H}_{2} \mathrm{SO}_{4}\right)$ during the leaching period. This was done primarily to determine the extent at which diluted acid was required to stabilize the $\mathrm{pH}$ between the ranges of $0.5-2$. The change in $\mathrm{pH}$ for the free $\mathrm{pH}$ run at $45^{\circ} \mathrm{C}$ is displayed in Fig 3. The free $\mathrm{pH}$ curve displayed an increase in $\mathrm{pH}$ levels for the initial acidic solution with a $\mathrm{pH}$ value of 1.07 up to alkaline condition reaching a $\mathrm{pH}$ value of 7.11 . This was expected with the high calcite concentrations observed during X-ray diffraction as calcite is known to stabilize low $\mathrm{pH}$ solution to a more neutral state.

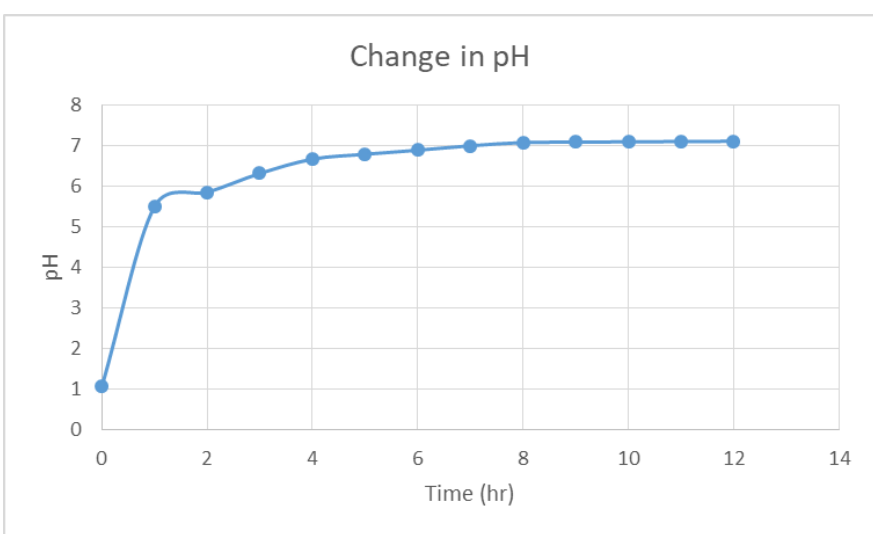

Fig 3: Free $\mathrm{pH}$ test

\section{B. Copper dissolution}

From the ICP data obtained after chemical leaching of the ROM sample at $200 \mathrm{rpm}$ and $45^{\circ} \mathrm{C}$ the copper dissolution curve is as displayed in Fig 4. For the purpose of this paper the effects of time on the dissolution of chalcopyrite ROM was observed as the measurable variable. The copper dissolution was mainly favorable as the trend of copper extracted displayed an overall increase in copper concentration starting at $202.45 \mathrm{mg} / \mathrm{L}$, after one hour of leaching, to $481.06 \mathrm{mg} / \mathrm{L}$ after twelve hours of leaching. The rate at which dissolution occurred had however decreased over the twelve hour leaching period with a percentage increase of $18.81 \%$ at two hours to $1.02 \%$ increase at twelve hours with a peak of $31.21 \%$ increase after seven hours of leaching. The effects of passivation formation on the surface of the chalcopyrite mineral is clearly visible with the low dissolution rate corresponding to $1.02 \%$ recovery increase from 11 hours to twelve hours of leaching. The effects of passivation is well understood and has been discussed in numerous studies [28]. The exact cause of passivation is still however up for debate as there is no general accepted theory as to the mechanism of the passivation formation [2].

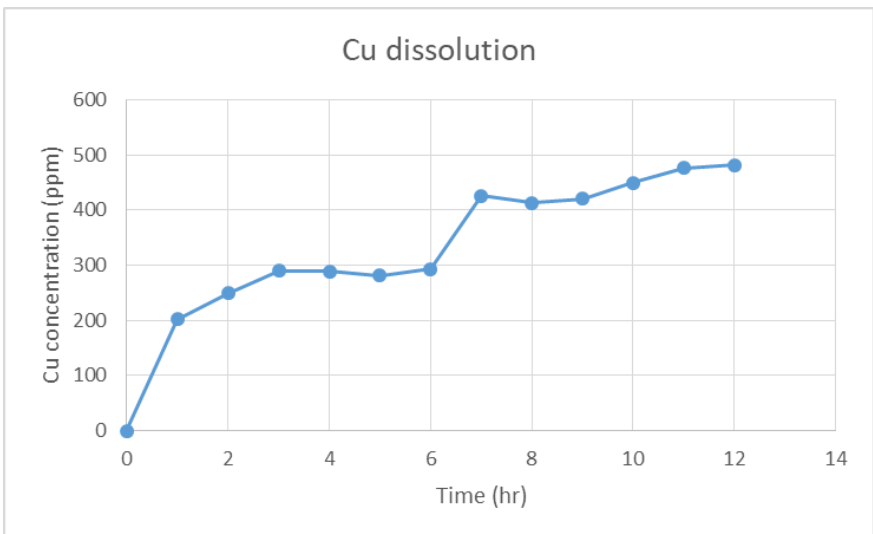

Fig 4: Copper dissolution rate at $45^{\circ} \mathrm{C}$

The dissolution of the major cations $(\mathrm{Ca}, \mathrm{Fe}, \mathrm{Mg})$ displayed similar behavior to that of copper with an overall increase in concentration ( $\mathrm{Ca}$ from $609.78 \mathrm{mg} / \mathrm{L}$ to $745.2 \mathrm{mg} / \mathrm{l}$; Fe from 
$4024.46 \mathrm{mg} / \mathrm{l}$ to $6316.58 \mathrm{mg} / \mathrm{l} ; \mathrm{Mg}$ from $912.028 \mathrm{mg} / \mathrm{l}$ to $4188.51 \mathrm{mg} / \mathrm{l}$ ) as displayed in Fig 5. Other cations with moderate concentration in the leachate were also present these being: Al (32.86-102.1 mg/L), K (56.33-136.7mg/l), Mn (31.67-95.16mg/l), $\mathrm{Na} \quad(48.1-66.55 \mathrm{mg} / \mathrm{L})$ and $\mathrm{Sr}$ (32.05-61.49mg/L). All major cation species also reached their peak of recovery after seven hours of leaching ( $\mathrm{Ca}$ at $29.15 \%$, $\mathrm{Fe}$ at $27.6 \%$ and $\mathrm{Mg}$ at $28.25 \%$ ).

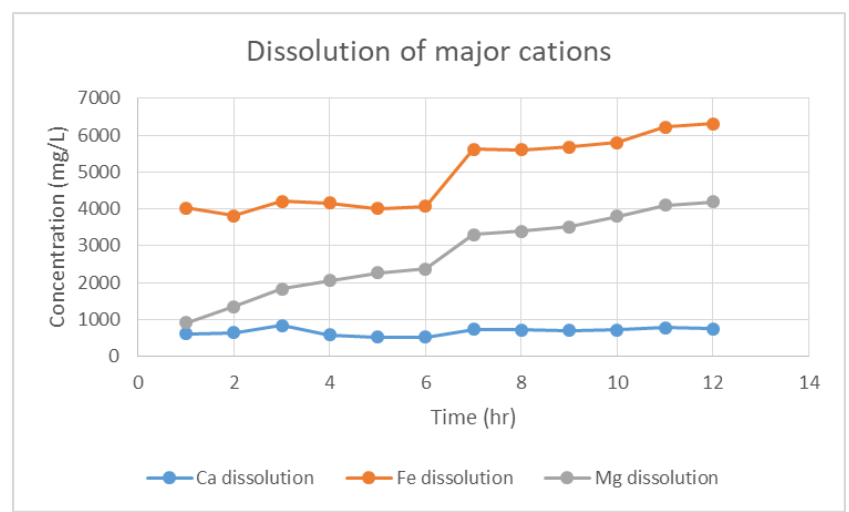

Fig 5: Dissolution of major cations

\section{Speciation results}

Species present during the twelve hour leaching period were accurately (less than $10 \%$ error) predicted using the PHREEQC workbench software. PHREEQC is effective in calculating the speciation of the major metals in terms of their free hydrated ions and inorganic complexes [[20]. The PHREEQC results are displayed in Table. The dominant species for calcium $(\mathrm{Ca})$, copper $(\mathrm{Cu})$ and magnesium $(\mathrm{Mg})$ were all present as salts $\left(\mathrm{CaSO}_{4}, \mathrm{CuSO}_{4}\right.$ and $\left.\mathrm{MgSO}_{4}\right)$. High concentration of free hydrated species of $\mathrm{Ca}, \mathrm{Cu}$ and $\mathrm{Mg}$ were also present $\left(\mathrm{Ca}^{+2}\right.$ at a range of 34.52-47.67\%; $\mathrm{Cu}^{+2}$ at a range of $34.47-47.67 \% ; \mathrm{Mg}^{+2}$ at a range of $39.92-51.64 \%)$. Other free hydrated species were also present but to a very low degree $(<1 \%)$. $\mathrm{Cu}$ and $\mathrm{Fe}$ were primarily present as cupric oxide and ferrous oxides, $\mathrm{Cu}(\mathrm{II})$ and $\mathrm{Fe}(\mathrm{II})$; the high concentration of ferrous oxides could be due to the reduction of the ferric sulphate oxidant. Cuprous oxides, $\mathrm{Cu}(\mathrm{I})$, and ferric oxides, $\mathrm{Fe}(\mathrm{III})$, were also available but at concentration $<1 \%$. Fe was primarily present in the free hydrated form of $\mathrm{Fe}^{+2}$ ranging from 76.62-87.58\%; it is the only major metallic species to be dominated by free hydrated ions. Other metals primarily present as free hydrates species were $\mathrm{K}$, $\mathrm{Mn}$ and $\mathrm{Na}$ as $\mathrm{K}^{+}, \mathrm{Mn}^{+2}$ and $\mathrm{Na}^{+}$respectively. $\mathrm{Fe}$ was also present as a salt $\mathrm{FeSO}_{4}$ at a low range of 12.39-21.77\%. Other free hydrated and complex hydroxide species of iron were also present but to a very small degree $(<1 \%)$. From the given data it appears that in a sulphate media it is not thermodynamically favorable for chalcopyrite $\left(\mathrm{CuFeS}_{2}\right)$ to oxidise directly to $\mathrm{Cu}^{2+}$ rather instead forming the salt $\mathrm{CuSO}_{4}$. From previous studies it was found that $\mathrm{CuSO}_{4}$ does not promote leaching in a sulphate system Error! Reference source not found.. Iron might also be released into the solution prior to copper which might also explain the low $\mathrm{Cu}^{2+}$ concentration [30]. This will explain the reduction in the dissolution rate from hour one to twelve from $18.8 \%$ to $1.02 \%$ dissolution rate of copper in the ferric sulphate media as the dominant $\mathrm{Cu}$ species is $\mathrm{CuSO}_{4}$ which gradually increases from hours one to twelve with an overall decrease in the $\mathrm{Cu}^{2+}$ concentration as well as an increase observed in the concentration of free hydrated iron species $\mathrm{Fe}^{2+}$. The general acidic conditions ( $\mathrm{pH}$ range $0.5-2$ ) could be the cause of the low hydroxide species concentrations as $\mathrm{Ca}$ hydroxide is primarily a strong base with $\mathrm{Cu}, \mathrm{Fe}$ and $\mathrm{Mg}$ being weaker bases forming under higher $\mathrm{pH}$ values.

TABLE I: SPECIATION RESULTS OF MAJOR METAL IONS IN THE LEACHATE OF THE ROM FEED SAMPLES

\begin{tabular}{clc}
\hline Elements & Species & $\begin{array}{c}\text { \% Range for ROM } \\
\text { samples at 45C }\end{array}$ \\
\hline \multirow{2}{*}{$\mathbf{C a}$} & $\mathrm{CaSO}_{4}$ & $52.26-63.48$ \\
& $\mathrm{Ca}^{+2}$ & $34.52-47.67$ \\
& $\mathrm{CaOH}^{+}$ & $<1$ \\
$\mathbf{C u}(2)$ & $\mathrm{CuSO}_{4}$ & $52.33-65.53$ \\
& $\mathrm{Cu}^{+2}$ & $34.47-47.67$ \\
& $\mathrm{CuOH}^{+}$ & $<1$ \\
& $\mathrm{Fe}^{+2}$ & $76.62-87.58$ \\
$\mathbf{F e}(2)$ & $\mathrm{FeSO}_{4}$ & $12.39-21.77$ \\
& $\mathrm{FeOH}^{+}$ & $<1$ \\
& $\mathrm{Fe}^{+}\left(\mathrm{OH}_{2}\right)_{2}$ & $<1$ \\
& $\mathrm{Fe}\left(O H^{3-}\right.$ & $<1$ \\
& $\mathrm{MgSO}_{4}$ & $48.36-60.08$ \\
$\mathrm{Mg}$ & $\mathrm{Mg}^{+2}$ & $39.92-51.64$ \\
& $\mathrm{MgOH}^{+}$ & $<1$ \\
\hline
\end{tabular}

\section{CONCLUSION}

The mineralogical investigation for ROM feed stream sample shows that carbonatite sample was mainly comprised of calcite magnesium (67.92\%) and dolomite (16.76\%) which agrees with the metal ion concentration obtained from the ICP analyses where calcium $(\mathrm{Ca})$ and magnesium $(\mathrm{Mg})$ were detected in higher concentrations than copper $(\mathrm{Cu})$ at a range of $609.78-745.24 \mathrm{mg} / \mathrm{L}$ and $912.03-4188.51 \mathrm{mg} / \mathrm{L}$ respectively. From the dissolution curve it is evident that the dissolution rate of copper reached a peak $(31.21 \%)$ after seven hours of leaching after which a gradual decrease in the rate of dissolution was observed. This could be due to an instant decrease in the concentrations of the copper salt species $\mathrm{CaSO}_{4}$ and an increase in the free hydrated ion $\mathrm{Cu}^{2+}$ due to favorable solubility. The gradual decrease in the copper dissolution rate after the peak dissolution was reached could be caused by the iron released before copper in the sulphate media leading to the low concentration of $\mathrm{Cu}^{2+}$ and higher concentration of $\mathrm{CuSO}_{4}$ which does not promote leaching. From the twelve-hour leaching run at $200 \mathrm{rpm}$ and $45^{\circ} \mathrm{C}$ the passivation effect on the chalcopyrite surface is visible with the overall decrease in the dissolution rate.

\section{REFERENCES}

[1] Schaming, J. (2011). An investigation of leaching chalcopyrite ore. Kingston.

[2] Li, Y., Kawashima, N., Li, J., Chandra, A., \& Gerson, A. (2013). A review of the structure, and fundamental mechanisms and kinetics of the leaching of chalcopyrite.

[3] Roll, D. (2014). Passivation and the Passive Layer. 
[4] Tshilombo, A. (2004). Mechanism and kinetics of chalcopyrite passivation and depassivation during ferric and microbial leaching .

[5] Vilca, A. (2013). Studies on the curing and leaching kinetics of mixed copper ores.

[6] E. Fosso-Kankeu, A. Mulaba-Bafubiandi, B.B. Mamba, T.G. Barnard, Assessing the effectiveness of a biological recovery of nickel from tailings dumps. Journal of Minerals Engineering. Vol. 24, pp. 470-472, 2011. https://doi.org/10.1016/j.mineng.2010.11.007

[7] E. Fosso-Kankeu, F. Waanders, A.F. Mulaba-Bafubiandi and S. Sidu, Leachability of suspended particles in mine water and risk of water contamination. $10^{\text {th }}$ ICARD/IMWA 2015; $10^{\text {th }}$ International Conference on Acid Rock Drainage \& IMWA Annual Conference. 21-24 April 2015 Santiago-Chile. Editors: Adrian Brown, Charles Bucknam, Joanna Burgess, Manuel Carballo, Devin Castendyk, Linda Figueroa, Lisa Kirk, Virginia McLemore, James McPhee, Mike O'Kane, Robert Seal, Jacques Wiertz, David Williams, Ward Wilson, Christian Wolkersdorfer. ISBN: 978-956-9393-28-0. Chap 4. Pp 1-9. 2015.

[8] E. Fosso-Kankeu, F. Waanders, and W. Botes, Recovery of Base Metals from Mine Tailings Dumps collected in the Vicinity of Potchefstroom: Leaching assisted by Complexing Agent. $7^{\text {th }}$ International Conference on Latest Trends in Engineering and Technology (ICLTET' 2015), November 26-27, 2015 Irene, Pretoria (South Africa). Editors: E. Muzenda and T Yingthawornsuk. ISBN: 978-93-84422-58-5. 2015.

[9] E. Fosso-Kankeu, F.B. Waanders, and A.H. Munyai, Susceptibility of Metals Release from Tailings Dumps Located In the Krugersdorp Area. $7^{\text {th }}$ International Conference on Latest Trends in Engineering and Technology (ICLTET' 2015), November 26-27, 2015 Irene, Pretoria (South Africa). Editors: E. Muzenda and T Yingthawornsuk. ISBN: 978-93-84422-58-5. 2015.

[10] A.H. Munyai, E. Fosso-Kankeu, F. Waanders, Biological influence on the mobility of metals from mine tailing dump located in Krugersdorp area. International Journal of Science and Research. ISSN: 2319-7064. Vol. 5, no. 4, pp. 1396-1403, 2016.

[11] A.H. Munyai, E. Fosso-Kankeu, F. Waanders, Mobility of metals from mine tailings using different types of organic acids: Batch leaching experiment. International Journal of Science and Research. Vol. 5, pp. 520-527, 2016.

[12] A.H. Munyai, E. Fosso-Kankeu, F. Waanders, Effects of organic acids on heavy metals released from mine tailings. International Conference on Advances in Science, Engineering, Technology and Natural Resources (ICASETNR-16) Nov. 24-25, 2016, Parys - South Africa. ISBN: 978-93-84468-79-8. 2016.

[13] E. Fosso-Kankeu, B. Barlow, N. Lemmer and F. Waanders, Geochemical speciation of metal ions in the leachate of tailings treated with synthetic rain water. $9^{\text {th }}$ Int'l Conference on Advances in Science, Engineering, Technology \& Waste Management (ASETWM-17). 27-28 November 2017, Parys, South Africa. Award winning paper. Editors: F. Waanders, E. Fosso-Kankeu, B. Topcuoglu, M. Plaisent, Y. Thaweesak. ISBN: 978-81-934174-6-1. Pp. 19-23. 2017.

[14] T. Moncho, I.G. Erdogan, M. Emandien, S.K.O. Ntwampe, E. Fosso-Kankeu, F. Waanders, A. Rand and B. Fourie, Prediction of metals bioavailability in the soils near mining areas in Okiep, South Africa. $9^{\text {th }}$ Int'l Conference on Advances in Science, Engineering, Technology \& Waste Management (ASETWM-17). 27-28 November 2017, Parys, South Africa. Editors: F. Waanders, E. Fosso-Kankeu, B. Topcuoglu, M. Plaisent, Y. Thaweesak. ISBN: 978-81-934174-6-1. Pp. 142-146. 2017.

[15] E. Fosso-Kankeu and J. Redelinghuys, Bacterial ecology of biofilms sustaining pollution by acid mine drainage near mining areas in Mpumalanga Province - South Africa. $11^{\text {th }}$ ICARD/IMWA/MWD Conference "Risk to Opportunity". 10-14 September 2018 Pretoria, South Africa. C. Wolkersdorfer, L. Sartz, A. Weber, J. Burgess, G. Tremblay.ISBN: 978-0-620-80650-3 Vol 1 (2 volumes). 2018.

[16] Beale, C. (1985). Copper in South Africa-Part I. Journal of the South African Institute of Mining and Metallurgy, 85(3), 73-80.

[17] Heinrich, E. (1970). The Palabora Carbonatitic Complex: A Unique Copper Deposit.

[18] J.K. Nyembwe, E. Fosso-Kankeu, F. Waanders, K.D. Nyembwe, Structural, compositional and mineralogical characterisation of carbonatitic copper sulfide concentrator plant streams: Run of mine, concentrate and tailings. International Journal of Minerals, Metallurgy and Materials. 2018.
[19] Heinrich, E. (1970). The Palabora Carbonatitic Complex - A Unique Copper Deposit. Michigan.

[20] Chakhmouradian, R., Reguir, E., \& Zaitsev, A. (2016). Calcite and dolomite in intrusive carbonatites. I. Textural variations. Miner Petrol, 333-360. https://doi.org/10.1007/s00710-015-0390-6

[21] A. Manyatshe, E. Fosso-Kankeu, D. Van Der Berg, N. Lemmer, F. Waanders, H. Tutu, Assessment of seasonal variation in surface water quality of the Mooi and Vaal Rivers network, South Africa. International Conference on Advances in Science, Engineering, Technology and Natural Resources (ICASETNR-16) Nov. 24-25, 2016, Parys - South Africa. ISBN: 978-93-84468-79-8. 2016.

[22] E. Fosso-Kankeu, A. Manyatshe, A. Munyai, F. Waanders, AMD formation and dispersion of inorganic pollutants along the main stream in a mining area. In: Drebenstedt, C. \& Paul, M.: IMWA 2016 - Mining Meets Water - Conflicts and Solutions. - p. 391 - 397; Freiberg/Germany (TU Bergakademie Freiberg). 2016.

[23] E. Fosso-Kankeu, Investigation of the oxidation rate of sediments from AMD using humidity cell test. International Conference on Advances in Science, Engineering, Technology and Natural Resources (ICASETNR-16) Nov. 24-25, 2016, Parys - South Africa. ISBN: 978-93-84468-79-8. 2016.

[24] E. Fosso-Kankeu, A. Manyatshe, F. Waanders, Mobility potential of metals in acid mine drainage occurring in the Highveld area of Mpumalanga Province in South Africa: Implication of sediments and efflorescent crusts. International Biodeterioration and Biodegradation. Vol. 119, pp. 661-670, 2017. https://doi.org/10.1016/j.ibiod.2016.09.018

[25] A. Manyatshe, E. Fosso-Kankeu, D. van der Berg, N. Lemmer, F. Waanders, H. Tutu, Dispersion of inorganic contaminants in surface water in the vicinity of Potchefstroom. Physics and Chemistry of the Earth. Vol. 100, pp. 86-93, 2017. https://doi.org/10.1016/j.pce.2017.04.008

[26] A. Manyatshe, E. Fosso-Kankeu, D. van der Berg, N. Lemmer, F. Waanders, H. Tutu, Metal speciation in the rivers around Potchefstroom based on seasonality. Water Environment Research. Vol. 90, no. 1, pp. 84-95, 2018. https://doi.org/10.2175/106143017X15054988926587

[27] Striggov, B. (2013). Field Measurements of OXidation-Reduction Potential (ORP).

[28] Cordoba, E., Munoz, J., Blazquez, M., \& Ballester, A. (2008). Leaching of chalcopyrite with ferric ion. Part I: General aspects. Hydrometallurgy, 93, 81-87. https://doi.org/10.1016/j.hydromet.2008.04.016

[29] Dutrizac, J. (1981). The dissolution of chalcopyrite in ferric sulfate and ferric chloride media. Metallurgical and Materials Transaction B, 371-378. https://doi.org/10.1007/BF02654471

[30] Lu, D., Wang, W., Xie, F., \& Jiang, K. (2016). Thermodynamic Analyses of Possible Chalcopyrite Dissolution Mechanism in Sulfuric Acidic Aqueous Solution. Shenyang. 